\title{
Managerial governance adaptation in the multinational enterprise: In honour of Mira Wilkins
}

\author{
Alain Verbeke ${ }^{1,2,3}$ and \\ Hadi Fariborzi ${ }^{1,4}$ \\ ${ }^{1}$ Haskayne School of Business, University of \\ Calgary, 2500 University Drive NW, Calgary, \\ AB T2N 1N4, Canada; ${ }^{2}$ Henley Business School, \\ University of Reading, Reading, UK; ${ }^{3}$ Solvay \\ Business School, Vrije Universiteit Brussel, Brussels, \\ Belgium; ${ }^{4}$ University of Sussex Business School, \\ Jubilee Building, University of Sussex, Brighton, UK
}

Correspondence:

A Verbeke, Haskayne School of Business, University of Calgary, 2500 University Drive NW, Calgary, AB T2N 1N4, Canada

e-mail: averbeke@ucalgary.ca
Mira Wilkins is a Fellow of the Academy of International Business (AIB) and Professor Emerita at the Department of Economics, Florida International University. https://aib. msu.edu/Fellow/66/Mira-Wilkins.

Online publication date: 16 July 2019

\begin{abstract}
We propose an analytical business history approach, informed by new internalisation theory, to study managerial governance adaptation in the multinational enterprise (MNE). We shed new light on the timing and the scale of managerial governance adaptation. These two issues have remained largely unaddressed in mainstream international business theory. We uncover the importance of delayed, larger-scale governance adaptation as a response to cumulative, localised commitment failures. We illustrate our new perspective on managerial governance adaptation by providing a short retrospective of Wilkins and Hill's (American business abroad: Ford on six continents, Cambridge University Press, Cambridge, 1964) classic historical account of Ford Motor Company's expansion across six continents between 1903 and 1963. Our brief retrospective highlights the value of in-depth historical analysis, informed by umbrella behavioural assumptions, such as those adopted in new internalisation theory-based research, to gain improved understanding of international strategy and governance trajectories of large MNEs.
\end{abstract}

Journal of International Business Studies (2019) 50, 1213-1230.

https://doi.org/10.1057/s41267-019-00251-7

Keywords: Mira Wilkins; new internalisation theory; multinational enterprise; bounded rationality; bounded reliability; subsidiary; multinational head office; managerial governance; adaptation

\section{INTRODUCTION}

Internalisation theory assumes that firms conducting international business (IB) transactions will engage in efficiency-driven decisionmaking (Rugman, 1981). These companies command idiosyncratic resource bundles that constitute firm-specific advantages (FSAs) deployable across borders. Internalisation theory, especially the Rugmanesque stream, was originally conceived to guide IB research and practice towards crafting efficient governance for exploiting FSAs. The Buckley and Casson $(1976,1998,2009)$ stream, the Hennart $(1977,1982)$ stream and the stream developed by Dunning and colleagues, see Cantwell (2015), Dunning \& Lundan (2008), and Narula (2010), had a somewhat different perspective, as carefully explained in Narula, Asmussen, Chi and Kundu (2019).

In contrast, new internalisation theory, which is the foundation of our analysis, focuses mainly on novel resource combinations to 
augment extant FSAs (Narula \& Verbeke, 2015). It also adopts a richer set of behavioural assumptions: MNEs will select governance models (including guiding principles, ownership and control forms, organisation structures and managerial governance systems) that economise on bounded rationality and bounded reliability (Verbeke \& Kenworthy, 2008; Verbeke \& Greidanus, 2009). Such governance models, aimed at economising, will facilitate commitment fulfilment when engaging in resource combinations, and value creation in its entirety, i.e., from developing new knowledge to delivering final products in the market place. Efficiencydriven governance choices will thus support exploiting extant FSAs to the fullest, and efficiently augmenting these FSAs through requisite new resource combinations in foreign markets.

Extant theory assumes that firms will make initial and subsequent governance model choices by selecting the most efficient model among a number of real-world alternatives. A large body of literature has demonstrated that this prediction is largely correct for initial governance model choices, subject to proper analysis of endogeneity conditions, as well as further qualifications, such as home and host country institutional drivers and constraints. Analysis of structural governance selection in multinational enterprises (MNEs) and the evolution thereof is well established and has been the subject of a particularly large scholarly literature (Buckley, 2018; Casson, 2018; Jones, 2005; Rugman, 2009). However, the challenge of governance adaptation when an initially selected model is no longer efficient, whether in an absolute or comparative sense, has largely remained a black box in IB research. This is in spite of excellent empirical work on ownership mode switches (Buckley \& Casson, 1981; Benito, Petersen \& Welch, 2009; Gao \& Pan, 2010), and commendable efforts to explain structural governance trajectories of MNEs (Stopford \& Wells, 1972; Bartlett \& Ghoshal, 2002; Rugman, Verbeke \& Yuan, 2011).

Managerial governance, with its focus on prevailing decision rules and practices or routines deployed within MNE governance structures, has also been studied extensively, but mostly with a focus on very specific governance tools in the areas of coordination and monitoring (Zeng, Grøgaard \& Steel, 2018), and usually without much longitudinal analysis of timing and scale issues, except in the IB history literature. However, it is managerial governance, rather than solely structural governance, that largely determines the economising capacity of the MNE, when combining resources for value creation in its entirety. A focus on managerial governance is consistent with the substantial Penrosean literature on firm-level expansion trajectories (Penrose, 1959, with a third edition published in 1995; Rugman \& Verbeke, 2002). As noted by Edith Penrose:

\footnotetext{
A firm's rate of growth is limited by the growth of knowledge within it, but a firm's size by the extent to which administrative effectiveness can continue to reach its expanding boundaries (Penrose, 1995, xvii).
}

One key challenge for IB researchers is that managerial governance adaptation, which may constitute the bulk of MNE governance model changes over time, is difficult to observe and track without an in-depth understanding of the firms analysed. Only a small number of well-known, case-based studies have succeeded in delivering such longitudinal analyses, most notably Doz and Prahalad's (1981), and Mees-Buss, Welch, and Westney's (2019) articles on organisational change in MNEs.

In this paper, we explore further when and how an MNE adapts its governance model, whereby we focus on its managerial governance systems, rather than its overarching approach to ownership and control or its organisational structure. As suggested above, managerial governance adaptation, as opposed to ownership and control, or organisational structure changes, remains mostly invisible when conducting larger-scale, quantitative empirical analyses. The specific question we try to answer is the following: Does the same, efficiency-driven decision-making that supposedly characterises initial governance choices by the MNE (as predicted by internalisation theory) also prevail in subsequent governance model adaptation, especially in the realm of selecting new managerial governance practices?

Our purpose is to describe the dynamics of managerial governance adaptation in the MNE, building upon internalisation theory thinking. We focus especially on the timing and the scale of managerial governance adaptation. We illustrate the importance of timing and scale by briefly revisiting the classic case study American Business Abroad: Ford on Six Continents (Wilkins \& Hill, 1964).

In the longer run, comparatively more efficient forms of governance should displace less efficient ones, at least in modern, social market capitalism. However, we should emphasise that we do not focus here on possible moves towards a 
hypothetical, 'most' efficient governance form in an absolute sense, supposedly instrumental to superior economic performance of the firm. Our view, in line with Williamsonian and internalisation theory thinking, is that in real-world settings and in the longer-run, comparatively more efficient forms of governance will prevail over less efficient ones. These will allow the improved unfolding of transactions - or more broadly - higher commitment fulfilments when combining resources, as a critical component of value creating processes in their entirety (Verbeke, 2013; Williamson, 1996).

The remainder of this paper is structured as follows. In the second section, we briefly describe the origins of the behavioral assumptions of new internalisation theory, importantly the bounded reliability concept and its significance to the field of IB strategy, with a focus on its implications for the managerial governance of the MNE. In the third section, we take a fresh look at managerial governance adaptation, considering the timing and scale of such adaptation. In the fourth section, we describe the value of business history analysis to address questions in the realm of MNE managerial governance, and we explain our choice of the 'Ford on Six Continents' case to illustrate our perspective on the timing and scale of governance adaptation. The fifth section briefly describes the dynamics of commitment failures and managerial governance adaptation in Ford's IB operations over a 60 -year trajectory, whereby we identify four critical periods with a distinct managerial governance approach. The last section concludes.

\section{From Strong-form Self-interest to Bounded Reliability}

Perhaps the most influential conceptual approach to explain governance design and adaptation has been the Williamsonian transaction cost economics (TCE) lens (Williamson, 2013). Here, a combinatorial notion of three dimensions is critical to governance analysis in terms of assessing its relative efficiency and the possible needs for adaptation. Higher asset specificity (referring to the problematic redeployment - meaning the loss of economic value - of resources committed to a particular 'contractual' purpose) typically requires more complex contracting to alleviate challenges of bounded rationality and strong-form self-interest. The levels of bounded rationality and strong-form selfinterest to be alleviated are themselves highly context-dependent, but one key implication, valid across contexts, is the need for governance adaptation in case contracting features become illsuited to changing input configurations of asset specificity, bounded rationality and strong-form self-interest.

There are, however, at least two limitations associated with the mainstream Williamsonian approach as far as governance adaptation in MNEs is concerned. A first limitation is that asset specificity is a somewhat oversimplified concept when addressing the challenge of novel bundling (or combination) of resources, especially in diversified MNEs. New market entries involve a variety of entry mode menus, and more generally changes in the firm's geographic activity portfolio. Such changes require ongoing choices about resources exploitation, upgrading/rejuvenating, and, more generally, recombining these extant resources with newly accessed ones (Teece, 2014; Verbeke \& Kenworthy, 2008; Narula et al., 2019). Similarly, global value chains, whereby a multitude of transactions across the MNE's network must be coordinated simultaneously, exemplify the challenges associated with conventional TCE-based analysis (Kano, 2018; Strange \& Humphrey, 2019, this issue). What matters much in diversified organisations such as MNEs, is not only addressing asset specificity (though this remains of critical importance), but having an arsenal of governance tools in place to secure ongoing commitment fulfilments as part of the above value-creation processes in their entirety. Here, new behavioural challenges arise continuously as the firm's geographically dispersed activity portfolio is altered (Hutzschenreuter \& Matt, 2017; Verbeke, 2013; Asmussen et al., 2019).

As noted above, it is important to distinguish between structural governance (such as the choice of formal relationships among MNE shareholders, board and top management; the overall organisational structure; choices of entry modes in international markets; etc.) and managerial governance, with the latter being the subject of this paper. Managerial governance refers to more fine-grained mechanisms within a broader governance structure, some of these being relational in nature, that encourage repeated, observable patterns of behaviour by targeted units and individuals. These range from narrow classes of individuals, such as $R \& D$ scientists, to all employees in the organisation, and even to the firm's external stakeholders; see Kano (2018). Whether these mechanisms are efficient will depend upon their capacity (relative to feasible alternatives) to influence the behaviour of the targeted economic actors within and outside the 
MNE, in terms of commitment fulfilment. The point is that within any given high asset-specificity context, continuous, or at least regular, recalibration of managerial governance tools will be required to match the needs of new resource combinations, especially when novel resource bundling occurs in international expansion moves.

The second limitation of Williamson's approach is that strong-form self-interest, though often observed in managerial practice, does not always materialise, even in contexts of high, one-sided vulnerability (Nordberg \& Verbeke, 1999). And commitment failures often do arise, even when strong-form self-interest is not a major concern, or when efficient managerial governance mechanisms are in place to curb it.

Recently, a new perspective has been introduced in internalisation theory that builds upon the combined effect of two behavioural assumptions: Here, bounded reliability complements the widely accepted bounded rationality assumption. The bounded reliability assumption suggests that individuals engaged in purposive economic organisation are reliable, but only limitedly so. It refers to individuals (and by extension sub-units, such as functional units, subsidiaries and even the head office) within the organisation - as well as to the economic actors with whom the firm engages in 'contracting arrangements' in the broad sense failing to make good on their commitments. Commitment failure beyond challenges of bounded rationality result from governance's inability to keep in check the propensity of individuals to become unreliable, i.e., their 'human frailty' broadly considered (Verbeke \& Greidanus, 2009).

When re-analysing Chandler's well-known account of the history of the DuPont and General Motors corporations (Chandler \& Salsbury, 1971), Kano \& Verbeke (2015) identified opportunism, benevolent preference reversal (reprioritising or scaling back on overcommitment) and identitybased discordance (regression or divided engagement) in large multidivisional firms as the main sources of commitment failure to be addressed through governance adaptation. Each source of commitment failure appeared to require a distinct set of managerial governance tools in the realm of ex ante prevention and ex post adaptation. The authors concluded that most observed commitment failures were unrelated to opportunism. Most importantly, the authors developed a multipronged conceptual framework of sources of bounded reliability that is parsimonious and readily applicable to large MNEs.

\section{THE TIMING AND SCALE OF MANAGERIAL GOVERNANCE ADAPTATION}

The above suggests that an initially efficient governance model may need to be adapted as the MNE changes its boundaries in product and geographic market space. Building upon internalisation theory thinking, Table 1 describes the complexities of such governance adaptation as a response to new resource combinations, and related (dangers of) commitment failure. Our brief retrospective of the Ford historical case study will demonstrate this point.

Table 1 describes the timing of managerial governance adaptation, as the MNE pursues a particular internationalisation trajectory. Is this adaptation swift (whether anticipative or corrective) or delayed, thus indicating cumulative failure, meaning that a palette of similar failures materialises across functions, products and geographies, and sometimes over a prolonged period of time? In terms of the scale of governance adaptation, a governance correction can be narrow (in terms of scope of targeted activities) and localised or it can take the form of a larger-scale correction, covering several functional areas, product lines and geographies. In the latter case, one could use the term 'wholesale' governance adaptation.

Table 1 allows us to distinguish between four cases. The first is representative of mainstream governance design thinking as used in internalisation theory. Starting from an equilibrium situation, with supposedly efficient governance mechanisms in place, new resource combinations will trigger swift, anticipative or corrective governance adaptation. Here, adaptation is narrow: it is a targeted intervention to solve the economising challenge associated with a specific new resource combination. It is also local, for example, implemented within a single foreign operation. Possible commitment failures will either be properly anticipated, and folded into governance design, or ex post remediation will occur. Thus, this represents the 'efficient alignment of governance features with resource combination characteristics' hypothesis, in the spirit of Hennart (2009). In mainstream MNE theory, and in the realm of structural governance, this approach is reflected, inter alia, in the choice of entry mode when penetrating a new market, especially the choice between external market 
Table 1 Timing and scale of managerial governance adaptation in MNEs

\begin{tabular}{lcc}
\hline Scale of managerial governance adaptation & \multicolumn{1}{c}{ Timing of managerial governance adaptation } \\
\cline { 2 - 3 } & Swift (anticipative/corrective) & Delayed (cumulative failure) \\
\hline Narrow/local & 1 & 3 \\
Wholesale/Organisation-wide & 2 & 4 \\
\hline
\end{tabular}

contracting and equity-based investment. It is also described in the literature on operating mode switches, for example when a joint venture is taken over by one of the partners to remediate conflicts and allow for better resource coordination inside a single firm.

However, three other cases might emerge, as shown in Table 1, whereby the scale and timing of governance corrections might differ from the basecase assumed by extant theory. The second case represents instances of new resource combination, whereby failures (realised or expected) may occur only in a narrow area of activity and at the local level, but wholesale governance changes follow. As a result of narrow and local experience (whether direct, observational or vicarious) with new resource combinations, senior management at the head office swiftly introduces organisation-wide economising practices, much in line with what is expected to occur in the "transforming" stage, in dynamic capabilities thinking (Teece, 2014).

In the third case, the MNE ultimately does engage in some corrective governance action at the local level, but it is delayed. A key reason is that management at the local level, typically in foreign subsidiaries, may pursue local goals (whether opportunistically or without malevolence), and senior management at the head office may underestimate the need for adaptation. The absence of senior management implementing the required change can itself often be attributed to a combination of bounded rationality (lack of adequate knowledge on the spatially dispersed governance challenges at hand), and regression (expressing identity-based discordance, triggered by the belief that practices which worked well in the past were better if they were not changed). Any governance adaptation typically takes the form of putting out highly visible, small fires (e.g., changing a manager or introducing an improved incentive system in a unit to achieve a desired behavioural change), rather than fixing the underlying main causes of these fires (e.g., by curbing excessive autonomy of subsidiary managers).
Finally, the accumulation of many, even minor, uncorrected failures throughout the organisation can over time amount to a large-scale failure requiring a massive change in strategy and governance by the MNE, as described by the fourth case in Table 1, which is perhaps the most understudied scenario in IB research. Here, uncorrected commitment failures that have cumulated over time ultimately lead to larger-scale, organisation-wide failures, that then require wholesale governance adaptation.

\section{Business History, Commitment Failures and Governance Adaptation}

As noted above, we briefly revisit a classic business history analysis of a large MNE, namely the Ford Motor Company (Ford, hereafter), as it expanded across six continents, over a 60-year period, between 1903 and 1963 (Wilkins \& Hill, 1964). It is the most detailed IB case study written on a single MNE. Its main author, Professor Mira Wilkins, has been credited with creating the modern field of MNE history, and her work has been described as "pioneering" (Jones, 2015: 403). Modern perspectives on MNE evolution acknowledge the value of detailed historical analysis of firm-level cases to augment extant MNE theory, especially in the realm of strategic decision-making and governance adaptation (Casson, 1997; da Silva Lopes, Casson, \& Jones, 2019; Narula \& Verbeke, 2015; Wilkins, 2009). Wilkins (2009: 3) notes that the: "most valuable contribution of business historians to the field of multinational enterprise is to provide a sense of process, change, accumulated experience, paths taken and not taken, the limits of choice, and the basis for the development of the tissue of multinational enterprise behaviour." Such understanding necessarily requires a three-pronged focus on organisational complexity, context, and analysis of discontinuities over time. Wilkins (2009: 20) further argues that the description of governance approaches provided by the business historian must necessarily acknowledge these approaches as being "fraught with nuance". 
Here, we should make two methods-related comments. First, Buckley (2016), a leading IB scholar, recently compared the strengths of historical analysis and mainstream social sciences research to explain MNE international expansion. He acknowledges historical analysis' capacity to provide an in-depth, context-rich understanding of the interdependence of variables, whereas mainstream social sciences research typically adopts a reductionist approach, focused on explaining how an independent variable affects one or more dependent variables. Buckley (2016: 881) further states that:

\begin{abstract}
Research in history therefore demonstrates the importance of time, sequencing and process. It also highlights the role of individuals and their decision-making. These elements are particularly important in examining entrepreneurship and individual (manager's) decisions and their outcome in contexts such as the internationalisation of the firm.
\end{abstract}

One key challenge, however, is that historical source materials are typically incomplete and not necessarily fully accurate, so that authors composing or interpreting a historical narrative must engage in requisite 'source criticism'. In this context, our interpretation of Wilkins and Hill's (1964) narrative represents only one attempt at reinterpreting this historical case study. Other scholars analysing these materials might come to complementary or even different conclusions.

Second, as a complement to Buckley's (2016) perspective, Gill, Gill, and Roulet (2018) describe the criteria that need to be respected for historical analysis to be considered the equivalent of an interpretive organisational analysis. Here, transparency is essential. This refers inter alia to rich contextualising of the historical case material analysed and critical engagement with high quality source material. It is also important to "reveal underlying assumptions" (Gill et al., 2018: 195).

The 'Ford on six continents' narrative is particularly powerful because both Mira Wilkins and Frank Hill had studied the history of the automotive industry for years, before writing this case study on Ford. Frank Hill had previously coauthored three volumes on the history of Ford with Allan Nevins, the Pulitzer Prize-winning historian, who was a Columbia University professor and had also been a visiting professor at the University of Oxford. As of 1958, Mira Wilkins had been working on the third of these volumes as a research assistant, after earning her PhD at Cambridge University. The Preface to the First Edition of 'Ford on six continents' and the
Bibliographical Essay at the end (pp. 445-458) impressively detail the extraordinarily wide variety and depth of the sources used to write the case, including archives from - and interviews with Ford executives from around the world. Nevins (1964: xxvii) characterised the book as "the most complete and scholarly account of the foreign activities of a great American industrial enterprise yet written."

In a recent paper that extends internalisation theory, based upon insight from historical case studies such as 'Ford on six continents', da Silva Lopes et al. (2019) contend that MNE governance forms, whether conventional hierarchies or more unconventional governance approaches such as those found in 'free-standing companies', typically have efficiency properties interpretable as firm-level responses to the demands of rich contexts. The authors focus on MNE entrepreneurship patterns and on the distribution of MNE head office functions over time, and usefully conclude that the evolution of MNE governance is substantially more complex than acknowledged in mainstream IB theory. Their analysis, which can be considered the state-of-the-art of IB history thinking, carefully explains the prevalence of particular governance forms as a function of their efficiency properties, given complex changes in business, economic, legal and political contexts, but it does not provide in-depth analysis of observed adaptation of managerial governance in terms of our own dual focus on timing and scale.

First, in terms of the timing of governance corrections, the authors do not distinguish between swift governance changes versus delayed corrections. Second, in terms of the scale of the governance changes involved, the authors usefully describe governance adaptation as either structural governance changes or as logical responses to welldefined, narrow and localised commitment failures. They do not, however, focus on large-scale, but more fine-grained, managerial governance adaptation, following novel resource combinations.

In accordance with Williamsonian philosophy and with internalisation theory thinking on the MNE, the authors emphasise introducing comparatively more efficient governance as a function of rich contexts, many of these embodying a variety of risks in the business, economic, legal and political spheres. The main insight useful to our analysis is that the modern MNE did not "develop down a linear path from a smaller and simpler version of itself" (da Silva Lopes et al., 2019), much 
in line with the essence of Wilkins \& Hill's (1964) narrative.

\section{FORD ON SIX CONTINENTS: MANAGERIAL GOVERNANCE ADAPTATION}

\section{Analytical Business History}

A careful reading of 'Ford on six continents' allows the identifying of more than 40 clear instances of commitment failures and the sources thereof. In most cases, these failures were unrelated to opportunism and represented good-faith commitment non-fulfilment, whether benevolent preference reversals or expressions of identity-based discordance. Importantly, and in addition to these numerous instances of managerial efforts to curb bounded reliability, we identified four distinct eras, in terms of managerial governance approaches to Ford's international business activities. Taking into account the main managerial governance theme of each era, as described below, we named the eras as follows: the experimenting parent company era (1904-1918), the Ford Bible era (1918-1928), the planned independence era (1928-1945), and the assistive, enabling parent company era (1945-1963). Below, we very briefly describe managerial governance adaptation efforts prevailing in each era, in response to both local and organisation-wide commitment failures, with a focus on timing and scale.

Ford's IB activities started soon after inception in 1903 in Detroit, Michigan. Only a few months after the firm started operations, a Canadian distributor was appointed and Robert M. Lockwood, who was experienced in handling exports of other American industrial products, was selected to handle other exports markets from a New York office. Soon after, exports started, and Ford cars were made available in various markets around the world. During six decades, sales offices, assembly plants, branches, wholly-owned companies and manufacturing sites were established in different countries. Four distinct managerial governance periods are especially visible within the 60-year time frame, each constructed around a prevailing theme of managerial governance. In each case, we try to uncover the resource combination dynamics that affected the timing and scale of governance adaptation when moving from one period to the next.

\section{The Experimenting Parent Company Era: 1903-1918}

We named this era the experimenting parent company era, because the governance choices made, though mostly efficiency-driven, were based on only limited insight into the options available, and foresight about their effects. Ford's Model A, introduced in 1903, and its subsequent variations (Models C, B, N, S, K, R), were the first steps towards implementing company founder Henry Ford's vision of creating inexpensive and reliable means of transportation, and soon attracted interest in the United States and in foreign markets. Robert Lockwood, acting as a commission-based export agent in New York, sold Fords to locations as far away as Australia, Asia, and Latin America (Wilkins \& Hill, 1964: 27). In parallel, Gordon McGregor, the manager of a horse wagon workshop in Walkerville, Ontario, convinced Henry Ford that, due to Canada's import taxes, creating a Canadian company to assemble cars under Ford's head office in Detroit was justified. The Canadian company (with Ford-US owning a 51\% share) would soon produce cars in Windsor, Ontario, and it would sell these in the Canadian Dominion and other British Commonwealth countries, since Canada enjoyed preferential import tariffs within this vast commercial empire. Ford's sales in the UK were managed through a series of agent companies, who passed the rights to other interested firms, facing difficulties in fighting prejudice against American cars. Natural and government-imposed market imperfections largely determined the entry mode strategy. In 1906-07, Percival Perry, a young manager who strongly believed in the quality of American production, achieved the first significant sales volume of Ford cars anywhere outside Canada and the United States, by selling 102 units. This early result showed promising ground for future expansion in the UK market.

Early activities such as the ones above seldom led to situations where actors showed significant failure in fulfilling commitments. Most transactions were managed on an arm's-length basis, and the only plant to make cars outside the United States, namely in Canada, was managed as a miniature replica. Located only 30 minutes of travel across the Detroit River, McGregor frequently visited Ford's premises in Detroit (location of the Highland Park plant), and later in Dearborn, greater Detroit (where the Rouge plant was built on the river Rouge), with Dearborn becoming the corporate head office after 1927. The few cases of failure to 
deliver on promises (e.g., when in the first year McGregor failed to produce the 400 cars he had aimed for) were handled cordially, and the parent company patiently provided better car models and technical and managerial assistance. Ford-US gave McGregor "free rein" from the start, due partly to the close relationship he had established with Henry Ford, and also to the proximity and frequent coordination with the head office.

As for Europe, there actually was insufficient commitment to the company by some local dealers (interpretable as reprioritisation), and this made Ford open its first European sales company in Paris in 1907, with H.B. White as regional manager. He supervised all European sales, replaced dealers, and vigorously tried to foster close relationships with them to encourage sales and prioritising Ford over local models.

The introduction of the Ford Model T in 1908 truly revolutionised Ford's sales around the world. Priced lower than any comparable car from rivals, the Model $\mathrm{T}$ fulfilled Henry Ford's vision of an automobile for the masses. Sales surpassed expectations everywhere, within and outside the United States (Wilkins \& Hill, 1964: 53). The firm's rapidly expanding international business, and the potential perceived for selling the Model $\mathrm{T}$ worldwide, convinced the US head office executives to manage international sales through salaried employees. Robert Lockwood, who worked on a commission basis, was content with even the modest levels of sales that he had delivered (e.g., in 1907, he had sold 277 cars and earned a commission of $5 \%$ of sales). However, the company had higher aspirations for its IB activities (Wilkins \& Hill, 1964: 41). As a result, Lockwood's export contract ended in 1910 and an internal "foreign department manager" position was created, reporting directly to Detroit executives. In Canada, the assembly plant was growing into a full-fledged manufacturing site, increasing its factory area by 600,000 square feet by 1914. Sales grew rapidly in the country, but importantly Ford-Canada sold 38-43 per cent of its output to export markets, which represented a volume between two and three times the exports from Ford-US. An assembly plant in Melbourne, Australia, and a vast network of dealers, facilitated further international sales.

James Couzens directed Ford-US' international sales. In 1909, he started a new branch for the company in England, appointing Percival Perry as the manager. Perry sold 1023 Model T cars in the next two years, justifying the creation of an assembly plant in England. Ford Motor Company (England) Ltd. was incorporated in 1911, wholly owned by Ford-US, and soon erected an assembly plant in Trafford Park near Manchester. The higher geographic distance, the difficulty of communication, and the less coordinated visions of Perry with Ford-US managers, resulted in more cases of commitment failures, compared with Ford-Canada. In 1913, there was a labor union strike in the Manchester factory, disturbing work in Ford-England (a case of overcommitment). Charles Sorensen, a top executive with Ford-US travelled to Manchester to support breaking up the union's power. Many purchasing and production practices were similar between Ford-US and Manchester. The marketing activities and the way dealers in England were managed, however, were very different. Perry allowed his dealers to represent cars from other brands. This was a practice sternly forbidden by Ford-US, as being instrumental to both reprioritisation and divided engagement. When questioned about this policy, Perry asked Ford-US to "not to interfere therewith, as our organisation has been built up with 'maximum terms for everybody'. At this time, Ford-US executives decided not to object further to this policy, and no governance correction was introduced (Wilkins \& Hill, 1964: 51). Perry's stellar performance on the sales side was likely one reason for the relative indifference of Ford-US towards the effects of bounded reliability. However, importantly, Ford-US at that time was addressing more immediate priorities such as mastering its unique moving assembly line, bringing the price of the Model $\mathrm{T}$ down further, and managing a growing network of international relationships. In other words, the head office itself was suffering from some level of overcommitment.

Governance maladaptation in other locations, with sometimes even more daunting commitment challenges, had a low priority for the US head office. In 1913, Ellis Hampton, Ford's export manager in New York, was selected as the manager of Ford's branch in Buenos Aires, Argentina, to expand the company's presence in Latin America. It was a 21-day voyage to get to Buenos Aires from New York. As such, hands-on governance proved to be a difficult task, and was associated with costs that were unjustifiable from Ford-US' perspective. Hampton would therefore receive "the fullest information he could and then make his own decisions" (Wilkins \& Hill, 1964: 57). Relying on his own managerial judgment, building upon the imperfect information at hand and the full authority given to 
him, he made inroads into many markets in Latin America by setting up a dealer network in Argentina, Brazil, Venezuela, Chile and Uruguay.

It was not until the early weeks of World War I, in August 1914, that the severity of commitment failures and the need for a major overhaul of managerial governance proved critical. During the war, Ford-England and Ford-Canada soon diverted their production capacity to address war matters and government requirements (e.g., producing ambulances, tanks, tractors, and later airplane engines). Ford-England became a government-controlled agency, which had its manager, Perry, dividing his time serving in various government capacities to help with the war effort. Despite Henry Ford's pacifist sentiments and anti-war actions, affecting Ford's image across Europe, Perry persistently argued that he had never "taken any action to communicate or impose his views upon this company" (Wilkins \& Hill, 1964: 64). FordEngland soon moved towards full manufacturing, due to import taxes imposed in 1915, as a wartime policy to support British industry and to gain revenue. This wartime tax remained in place long after the war.

Amid the modest performance of H.B. White in France, a growing confidence in Perry's capabilities, and, importantly, the difficulty of governing European operations in wartime from the United States, Perry pressed for more control over Ford's operations on the continent and senior management at the US head office was agreeable. Perry started a French Ford company in 1916 ('Automobiles Ford') and fulfilled the French government's orders from that location and from Manchester. The multiple responsibilities throughout the war, however, soon had a deteriorating effect on his health, and on his reliability in light of the blind 'trust' that he had been given by Ford-US executives. As early as 1918, his biased prism, which had led to reprioritisation and divided engagement, were brought to the attention of Frank Klingensmith, Ford vice-president and treasurer. It was a charge fiercely rejected by Perry. A further investigation by William Knudsen, a Ford-US executive sent to England, criticised Perry's approach of engaging in political work unrelated to the company, and some of his actions that appeared contrary to Ford-US policies (e.g., the British government was manufacturing and selling tractors using Ford's factories in the final years of the war, and this was continued after the war). As a result, later in 1919, Perry was asked to resign. This, as we explain below, did not amount simply to a "change of men" (Kano \& Verbeke, 2015: 104) in only one Ford subsidiary and resulting from narrow area, localised commitment failures and related governance challenges. Rather, it was one highly visible expression of a much larger-scale, governance correction scheme imposed by Ford-US to compete in what was perceived to be a new era of required, improved local implementation of worldwide corporate goals.

\section{The Ford Bible Era (1918-1928)}

As we explain below, the Ford Bible era reflected a quantum move toward formal, routinised practices imposed on all of the company's foreign operations, with the exception of those in Canada and those served by Canadian operations (the British Empire minus the United Kingdom). The end of World War I triggered many macro-level changes. The distribution of power and wealth had shifted from crippled European nations towards the United States, which had been less affected directly by war, but had significantly increased its industrial output. There was growth in the automotive industry all around the world. During 1919, Ford's foreign and domestic sales reached an all-time high of one million units (Wilkins \& Hill, 1964: 89). Henry Ford's son, Edsel, had become the president of the company and the Ford family strengthened its ownership grip in Ford-US and other affiliated companies around the world. Ford-US executives were now closely involved with foreign operations. New companies and assembly plants were formed in Spain and Denmark. In the early 1920s, all European Ford companies had American heads, with their activities closely monitored by the head office.

Ford-US, at that time rejected any demands for more independence of action in foreign operations, constantly reminding its managers that they were "owned by the Ford interests and subject to instruction from the home office." Detailed letters of instruction were sent with directions on accounting, sales, production and purchasing. Each company had binders that detailed the routines to be respected. These formal instructions became known among employees as "the Ford Bible" (Wilkins \& Hill, 1964: 100). In England, Perry's policy of allowing dealers to sell cars of other brands alongside Ford's was now prohibited, which came as a shock to many dealers. Many resisted at first, but had to comply. In Spain, dealers had been adding comfort and luxury features to the car to appeal to local needs. Such actions were now 
strictly forbidden and the dealers were advised "that they have either got to quit it or quit selling Fords" (Wilkins \& Hill, 1964: 101). Ford-US had thus engaged in a wholesale standardisation of practices, in line with proven home-country recipes. Thanks to the growth in the automobile industry, the demand for Ford cars was kept solid, and sales increased across its dispersed geographic markets.

When a recession hit in 1920-21, Ford-US doubled down on the new governance approach. In the United States, Henry Ford had engaged in significant downsizing of factories and reductions of expenditures. Executives were discharged, including Frank Klingensmith, in part due to their desire to have more independence. Standard practices were forcefully imposed on foreign branches. Of all the European managers appointed in 1919, only James Harrington of Ford-Denmark remained. He was now appointed as the general manager for European operations. In Latin America, Ellis Hampton had vastly expanded Ford's operations with branches and assembly plants. To address declining sales due to the recession, emissaries were sent from the US head office to review management practices in Ford branches and to find new efficiencies. Expressions of divided engagement by managers, even small ones, were no longer tolerated, even when the managers involved had been highly successful and had proven to be vital to Ford's business success. Even Ellis Hampton was discharged for going against company policy and owning interests in one of the dealers. Soon, "heads were sent rolling", and all South American branches received new managers (Wilkins \& Hill, 1964: 109). Overall, the recovery from the recession was rather quick, and Ford's sales, owing in part to more efficient operations, soared back in 1922-23.

New companies were formed in Italy and Belgium in 1922, and Ireland was now manufacturing Ford tractors, named Fordson. Ford executives, and importantly, Edsel Ford and his brother-in-law, Ernie Kanzler, were showing a growing interest and paying much closer attention to overseas matters. A conference of foreign managers at Ford-US in late 1923 gathered for the first time the heads of all of Ford's European and Latin American companies. Ernie Kanzler attended the conference after spending two and a half months in Europe surveying growth perspectives. He was convinced that, due to industry expansion and the competition slowly lining up against Ford in Europe, it was time to speed up growth in international markets. Managers of foreign branches were therefore anticipatively encouraged at the conference to speedily expand their dealer networks. They were instructed not to get "overburdened with details", and that "prompt selection of agents is more important than finding the right man" (Wilkins \& Hill, 1964: 136).

The Ford-England managers observed a shift of the prior governance approach, revolving around coercing English dealers to exclusively represent Ford cars, towards 'persuasion' of these dealers on the advantages of selling Ford cars only. This managerial governance adaptation was the result of Ford's fast growth strategy for Europe, and viewed as likely to be a more efficient governance approach than the 'iron fist' approach used against dealers, while at the same time addressing remaining commitment failures, as some dealers tended to engage in regression to the old practices of representing multiple brands, in spite of the formal rules not to do so.

A few years into the new managerial governance era of Ford-US imposing standardised policies, and expecting adherence, the costs of this governance adaptation became increasingly apparent. As one example, in 1924, a Ford executive sent to England to assess expansion of manufacturing in that country found multiple deficiencies with respect to local manufacturing, purchasing policies leading to higher overall costs of the car, and many conflicts with dealers. Ironically, before this visit, Ford executives had expressed their satisfaction with the Ford-England manager, C.L. Gould, for he was thought to follow directions strictly. However, Gould was particularly forceful towards dealers, dumping cars on them that they could not sell, and cancelling agreements at any sign of complaint. This brought to the surface a clear divided engagement with what had been advised by US head office executives as to how the dealer network should be handled. "A bunch of clowns ran the English company", was the verdict of the Ford executive sent to Manchester. The supposed clowns had, however, been put into these executive positions by the head office and had been given strict directions to follow (Wilkins \& Hill, 1964: 141). In order to mitigate the many problems at hand, technical managers and engineers were sent from Ford-US to help solve purchasing and manufacturing problems, and C.L. Gould was replaced by H.S. Jenkins, Ford's manager of the Argentinian branch.

Added to the managerial governance challenges above was the rising competition in Europe, as 
early as 1923. In France, Britain, and Italy, car manufacturers had adopted Ford's manufacturing methods and were introducing smaller cars with lower maintenance costs to the market. In England, Ford's sales were showing a slight decline, and in 1924 the firm lost its place as market share leader for the first time in 12 years. Import taxes further amplified the need for the large-scale manufacturing of cars in Britain to be sold across Europe, thus reducing costs. By 1926, the Ford Model T, then in its 18th year of uninterrupted success, was facing increasingly successful competing models from rivals. By 1928, more efficient models were outselling Fords in Britain, pushing the company down to fourth place in terms of sales, and Ford cars were also not positioned in the top three selling cars in France or Germany. There were clear signs that new car models were needed, but also a new growth plan, and likely a governance correction that would allow more entrepreneurial responses to novel resource combination needs at the local level, whether at the supplier or the dealer side. One could reasonably argue that the strict standardisation of practices imposed by the US head office had become inefficient in the more competitive business environment, with the head office suffering from substantial bounded rationality challenges, and having itself become prone to divided engagement, in the sense of favouring inadequate head office solutions at the expense of subsidiary entrepreneurship.

\section{The Planned Independence Era (1928-1945)}

The planned independence era, as described below, promoted entrepreneurship in foreign affiliates, but largely of the head office-induced kind, and subject to careful planning involving the corporate head office.

The Model A (not to be mistaken with the first Model A car introduced in 1903) was introduced in late 1927, and Ford factories that had halted manufacturing older models earlier that year were engaged in a changeover to produce the new car. More important changes were, however, underway to meet the demands of a growing automotive industry around the world, with many new competitors which could threaten Ford's success. The need for volume manufacturing in Europe that would have unit costs comparable to those of cars made in the United States had long been recognised by Ford executives. Henry Ford set sail for Europe, arriving in Britain in April 1928. He was envisioning a British plant, which would be "the
Detroit of Europe" (replicating the Rouge plant), making 200,000 cars per year, to meet the entire European demand.

At that time, he was well aware that insisting further on sending directives from the United States, and compelling host country managers to implement these directives to the letter, was not what the company needed. The European environment had become a much more competitive scene with rapidly changing customer tastes across the region. Ford-England had seen five managers in charge over a 9-year period, and the many instances of their failure in meeting commitments made Henry Ford doubtful that the current governance was appropriate for the new era, especially in light of the ambitious growth plans.

He found Dagenham, Essex, to be a suitable location for the factory, and picked no other man than Percival Perry, the well-known manager discharged in 1919 , to share this new vision and to run the company during the new era to come. Perry accepted the challenge, and soon visited the US head office to craft detailed plans. The "1928 plan" as it was later called, was devised by Perry, Charles Sorensen, and Henry and Edsel Ford, and would change Europe's automotive industry. Ford-US would own 60 percent of shares in Ford-England to allow strategic control, and the other 40 percent would be distributed in small lots among the British public. Similarly, Ford-England would own 60 percent of the shares in the nine European Ford companies, and the rest of the shares would be distributed to nationals of each country. In addition, managers and some of the directors of the companies would be nationals of the countries where the subsidiaries were located. The above structural governance adaptation was meant in part to reduce the prejudice against Ford being an "American" company, in a world with increasing nationalistic sentiments that could make resource combinations difficult with actors such as suppliers and dealers, but also with government regulators and employees. The Dagenham factory would thereby direct Ford continental companies as a type of regional head office.

In planning the changes in Europe, Ford executives had largely emulated the decentralised governance approach that had worked well for them during more than 25 years with Ford-Canada (though the products themselves were the same as those manufactured in Detroit). From 1904 to 1922, Gordon McGregor, and then his successor, Wallace Campbell, had managed Ford-Canada with 
minimal commitment failure issues. Even through the Ford Bible era, Ford-Canada personnel never received letters and instructions about routines or practices to be strictly adhered to. Head officeaffiliate interactions were mostly informal and occurred largely through frequent consultation between McGregor (and later Campbell) and Ford head office executives. Canadian managers closely followed American routines, but where more efficient used their own judgement. Continuous open communication left little for the head office executives to worry about in terms of bounded reliability (Wilkins \& Hill, 1964: 116).

Ford wanted to repeat this proven success on a larger scale with Ford-England. In "the 1928 plan", Ford Model A and Model AF would be manufactured in three factories, namely in Ford-US, Ford Canada and Dagenham (UK), and each would in turn govern "a group of foreign assembly plants and marketing companies" (Wilkins \& Hill, 1964: 195). By the mid-1930s, the reorganisation of all European companies had been completed and they all had new directors and managers, almost all nationals of their respective countries. Construction at Dagenham had started in 1929, and in 1930 was showing fast progress, and growth plans were being implemented across Europe.

The overall plan was made in a prospering world, with much enthusiasm about the future. The volatilities lying ahead in the 1930s, however, would soon put the plan to a serious test. These volatilities increased due to the Great Depression in 1929, the extreme nationalist sentiments rising around the world, and finally World War II at the end of the decade. The effects of the 1929 Great Depression were harshly felt a year after. The recession caused an immediate shortage of financial liquidity throughout Europe. The automotive industry was experiencing a significant decline and Ford's European managers were failing to meet their sales commitments one after the other (instances of overcommitment). In addition, to protect American industry, the US congress passed the Smoot-Hawley Act, which significantly raised import tariffs, causing European governments to retaliate through similar tariff increases.

Ford-US's response to the continuous commitment failures of its affiliates shows a clear change of approach as compared to the previous era. For example, in response to the poorly received Model A in England that cost more than smaller British cars, Perry implored the head office to design a new car. Back in 1925, a similar request by Ford-England managers had been rejected outright by Henry Ford (Wilkins \& Hill, 1964: 144). In this new era, the US head office was quick to respond with designing a "baby" Ford, named Model Y. For the first time in Ford's history, a car had been designed in the United States specifically to meet the requirements of a particular foreign market. The car went to volume production by late 1932. By the end of 1933, and with a slight improvement in the economy, Dagenham had built 33,000 Model Y cars out of total vehicle output of 55,000 units.

The rising tariffs and increasing nationalist attitudes were another factor that created new complexities in governing international operations in the 1930s. Importantly, in Germany, the National Socialist party had in 1930 gained increased representation in the Reichstag. During his visit to Germany in 1930, Henry Ford discovered that the high tariffs and the increasing nationalism left no option but to manufacture in that country. He selected Cologne as a potential site for this purpose. This way, in his mind, he would prevent a possible commitment failure by English and German Ford managers in the future that would result from challenges of overcommitment, reprioritisation and, especially, divided engagement. The situation was similar in France. Maurice Dollfus, a former banker who had gained some experience in Ford-France, was later that year selected by Perry to be the manager. From the outset, Dollfus appeared boundedly reliable, in that he exhibited behaviour akin to divided engagement with Perry. Dollfus pursued manufacturing in France rather than the UK, supposedly to fight high import tariffs. Perry, already knowing he had lost Germany as a market, was unhappy with the prospect of being cut out of the French market. Given the absence of alternative feasible courses of action, Perry accepted the change and also reconciled himself with no longer being able to direct affairs in these two countries. Ford-Germany started manufacturing in Cologne as soon as 1931, and Ford-France in 1934.

The Great Depression, rising production costs, and increasing competition had led to a constant stream of narrow and local commitment failures by Ford's European managers, who would appeal for help from Ford-England and Ford-US. In response, constant consultation occurred as well as the supply of further resources to enable affiliates to meet commitments or to mediate discordances. For example, Edmund Heine, Ford-Germany's manager in 1932, was in desperate need of a new car model to lower his mounting losses and pay back debts to 
Ford-US. He asked approval to produce the Model $\mathrm{Y}$, which had been designed for Ford-England. Perry objected that this would both handicap Dagenham's sales and would need a further investment in the Cologne factory. Ford-US, however, agreed to provide the required funds. It also mediated the divided engagement and asked Perry to share the Model Y with Ford-Germany (Wilkins \& Hill, 1964: 247).

The managerial governance approach for this era appeared to have been weathering the many storms that hindered the fulfilment of a variety of narrow and local commitments by Ford's affiliates, helping them achieve high levels of output and profit in the last years before World War II. Nonetheless, a severe divided engagement of Ford affiliate managers, considering themselves to be patriots who put service to country above their commitments to Ford, led to a long stream of commitment failures. By 1939, Ford factories in Canada, France, Germany and Britain were greatly involved with fulfilling their respective government needs in the realm of war preparation. At a gathering of European managers in 1939, Perry underlined "Mr. Ford's... hatred of war" and emphasised "how necessary it was that everyone connected with the organisation should refrain from taking sides" (Wilkins \& Hill, 1964: 307). Nevertheless, he and his associates were themselves acting as patriots who devoted their own company's resources to the defence of the UK.

Later, as war broke out, the discordance and related misalignment with parent company policies would drastically increase, ultimately leading to a collapse of the existing governance mechanisms. When the German army invaded European countries, one after another, Ford facilities in the occupied countries were forced to serve the Nazi regime. In the Allied camp, Ford-England and FordCanada were rapidly increasing output to fulfil government contracts for war material. With the United States entering the war in late 1941, Ford-US also got involved with manufacturing war materials at its full capacity. The communication between Ford-US and its European affiliates was now limited, e.g., with reports of allied bombers trying to destroy Ford factories as they were being used by the enemy! A period with rigid, central governance being largely absent and foreign affiliates systematically reprioritising commitments and engaging in divided engagement so as to serve wartime government goals, concludes this managerial governance era.

\section{The Assistive, Enabling Parent-Company Era (1945-1963)}

The difference with the previous period is that, in the assistive, enabling parent-company era, head office direction would result from supposedly specialised knowledge about the international environment, and the main goal would be to empower entrepreneurial subsidiaries to create value in its entirety, from innovating through local car design to delivering their products to the rest of the world.

World War II ended on September 2nd, 1945, and the post-war era would greatly affect managerial governance at the Ford Motor Company. Shortly after the end of the war, the 82-year-old Henry Ford resigned and recommended his grandson, Henry Ford II, as his successor. Edsel Ford had passed away in 1943 and Charles Sorensen had resigned in 1944. The 28-year-old Henry Ford II found himself as the president of a crippled organisation that had to address the loss of key executives, the immediate need for new car designs, new government regulations imposed on the industry, and strong competition from General Motors and Chrysler. Henry Ford II started reorganising by adding key figures to the management team in the United States, including top executives who had worked for General Motors, which was Ford's main competitor.

In the international arena, for a short period after the war, the existing governance system remained in place. Ford-England oversaw Europe, FordCanada managed international activities in the British Empire and Ford-US' exports office managed direct sales to Latin America and other parts of the world. The new era, however, was much different from that of the late 1920s when Henry Ford had envisioned governing worldwide operations outside of the United States through only two main affiliates (England and Canada). Ford's international business post-World War II had to accommodate customer preferences requiring constant product innovations, changing government regulations and - importantly - increased competition from many American and European manufacturers. In addition to these new challenges, the final years of World War II had brought communication and coordination between Ford-US and its foreign affiliates to almost a standstill. Besides, the senior management teams in Dearborn and in Ford's foreign affiliates almost completely changed after the war.

By 1948, after the management team overhaul in the United States, Henry Ford II wanted to change 
the managerial governance design for foreign affiliates. As a first step, in 1948, he travelled to Europe. In Britain, Sir Patrick Hennessey, the new manager of Ford-England, welcomed him and explained the many problems facing the European operations. Among the important issues were the British government's imposing on Ford-England the requirement to export more than half of its production, and the related need to export worldwide, and the immediate need of Ford-England to introduce small cars to appeal to the British public. Although Henry Ford II promised the support of the head office in Dearborn to engineer the cars needed in Europe, this appeared unfeasible because of an overload of engineering tasks at Dearborn. Henry Ford II therefore responded to Hennessey's plea for more engineering support by stating: “...you'd better take care of your own problems" (Wilkins \& Hill, 1964: 366), which paved the way for local car design.

Another important policy change, soon to be applied everywhere in Ford's international business, was allowing Ford affiliates for the first time to make their products "available in all markets, the consumer making the decision". In other words, all Ford companies could market their product all around the world, including the United States. After travelling to Germany, France and other European companies, Henry Ford II observed that, in addition to mounting disorganisation in the postwar period, there was significant confusion with respect to policies, priorities, and the relationship with the head office. The benefits to FordEngland of continuing to hold shares, and to control policy in Ford's continental companies, was unclear. Ford-Germany and Ford-France were both also facing substantial challenges. They needed, inter alia, new capital investments to repair and expand factories, as well as technical assistance to improve manufacturing efficiency, and new car designs.

A new governance approach was announced in June 1948 at a conference involving managers from all international branches, including Europe, Latin America, and Asia. Henry Ford II announced that a new "Ford International Division" would be formed (as a structural governance change), to replace the "preposterous former state of affairs", reflecting cumulative commitment failures across geographies and functions. He added that the "principal office... [would] formulate the over-all policies... this is an American company and it's going to be run from America" (Wilkins \& Hill, 1964: 370). Importantly, from a managerial governance perspective, Ford-US as well as Ford's foreign manufacturing sites, including Canada, England, France and Germany, would be allowed to sell their cars in all markets. One important governance change that would affect the Canadian affiliate was that it would be controlled by the new international division, and would lose its autonomy over sales in the British Commonwealth countries.

Henry Ford II planned to transform international head office-affiliate relationships, from subsidiaries committing to fulfil the requirements set upon them by the head office, towards operating a harmonised body of units that can "market a large range of cars without having several factories building the same kind of car" (Wilkins \& Hill, 1964: 367). This vision represented a significant departure from Henry Ford I's "1928 plan" to make one car all around the world. The new goal required subsidiaries operating in harmony with the head office as far as governance in general was concerned, but also having enough enterprising and engineering capabilities, so that they could introduce new products and thrive on their own in the marketplace. In effect, foreign affiliates were provided with both support and independence (Wilkins \& Hill, 1964: 384). This was effected through sharing skills in management and production, enabling local product development, supplying market research and marketing techniques, purchasing on an international scale and, importantly, through significant investments in the foreign companies.

In the case of Ford-England, for example, the head office provided technical support as well as encouragement and approval to expand its own engineering force. In 1939, Ford-England had only 101 employees in its engineering group. The number grew to 270 by 1950 . The engineering personnel worked in close communication with Dearborn and could rely on the head office for "off-the-shelf service from any area of their vast engineering resources" (Wilkins \& Hill, 1964: 411). As a result, in 1950, Ford-England was ready to introduce its first two postwar cars to the market. Similarly, in Germany, a cooperation between German and American engineers led to the introduction of a new car in 1952 (Wilkins \& Hill, 1964: 392). FordGermany needed much more help as compared to Ford-England, as it lacked managerial resources and did not have a large engineering department. The head office also helped to rebuild and expand the German factory through providing capital 
investment, managerial expertise and sending talented human resources to work in the company.

As a result of these changes, in 1952, two FordEngland cars, one Ford-Germany car and another postwar model designed by Ford-France were all available in markets around the world. Two examples illustrate the efficiency and significance of the above governance adaptation. In the late 1940s and early 1950s, Latin American markets, as well as the growing market of Australia, experienced substantial demand for small, inexpensive cars. The rising production costs in the United States and in Canada, and the typically larger and more expensive cars made in these countries, would have left Ford with no car models that could lead to significant sales in these markets. In fact, it was the encouragement and enabling of Ford-US that helped Ford-England fill this gap and sell small cars to markets with demand for them. Dagenham's exports in 1948-49 amounted to more than 90,000 units, which represented more than $60 \%$ of its total sales at that time. Similarly, in the midst of a recession in late 1957, the American public rather suddenly also became interested in small cars with lower operation costs, and American manufacturers had little to offer to meet this demand. Ford, however, could respond positively to this emergent demand through " 17 foreign economy cars... the widest range... available in America". Ford-England's and Ford-Germany's exports to the United States surged as a result.

\section{Dynamics of Managerial Governance Adaptation}

We have argued that the extant scholarly work on managerial governance in large MNEs, especially the work informed by internalisation theory, has paid relatively little attention to two important dimensions of managerial governance choices, namely the timing and scale of governance adaptation. Mainstream MNE theory assumes that firms will design managerial governance systems to avoid commitment failures, and that any narrow and localised failures will be corrected swiftly and decisively. Managerial governance practices will be set up to economise on bounded rationality and bounded reliability. If new resource combinations, whether driven by internal entrepreneurial actions or imposed through external forces, make prevailing practices less efficient and lead to commitment failures, these will be corrected by introducing comparatively more efficient governance features. The base-case of supposed MNE decisionmaking is one of narrow and localised governance adaptation in response to narrow or localised commitment failure.

However, we have uncovered a much more complex reality in our retrospective of the Ford case. Our proposed framework, depicted in Table 1, allows distinguishing between four cases. The first, as explained earlier, is representative of mainstream work informed by internalisation theory: narrow and localised commitment failures are swiftly curbed by anticipative governance choices and $e x$ post remediation. The early management of Ford's subsidiary in Canada, during the Experimenting Parent Company era describes relatively well the relevance of this, though the observed adaptation (whether in Canada or elsewhere) was indeed largely experimental, rather than reflecting deep head-office insight into what would constitute efficient governance.

Second, a very different set of instances observed by Wilkins and Hill (1964) is represented in Table 1. Here, larger-scale managerial governance adaptation is implemented in a somewhat anticipative fashion and imposed on a large number of affiliates, based on narrow and local experiences. The Ford Bible era is illustrative, with the principle of repeatability at the core of imposing a wide variety of standardised routines across functions, products and geographies (but excluding Canada and the British Empire areas it served), so as to make sure that local operations would not deviate from firm-level priorities.

The relevance of the third case in Table 1 is illustrated by the delayed response to the commitment failures mushrooming in Ford's European subsidiaries in the context of World War II, in the middle of the Planned Independence era, with subsidiaries actually manufacturing vehicles and equipment for opposing sides in the war, and virtually ignoring any commitments, whether explicit or implicit, towards the parent company. Here, many needed governance corrections were delayed, and, to the extent any were made by the head office, these were typically narrow and localised, and ultimately ineffective in addressing the systemic nature of the failures at hand.

Most importantly, 'Ford on six continents' compellingly demonstrates the relevance of the fourth case in Table 1 to our understanding of the complexities of managerial governance adaptation. After the Ford Bible era, the two subsequent transitions to another governance era, namely those of Planned Independence and the Assistive, Enabling Parent, largely reflected the delayed introduction 
of larger-scale governance adaptation as a response to massive, cumulative commitment failures. Correcting the multiple failures took several years, with the head office trying not only to make sense of the narrow and local failures observed but also then designing a new managerial governance approach as a wholesale solution, deployable in the firm's entire internal network of operations. Here, a feature that could be added to the analysis, but which we have not focussed on, would be the scope of the managerial governance changes involved, for example by identifying whether particular clusters of functions or value chain activities were targeted specifically, or as a priority, in the delayed, largescale governance adaptation.

\section{CONCLUSION}

Our retrospective's main conclusion is that it may be instructive for IB researchers to study, over prolonged periods of time, the dynamics of new resource combinations in MNEs, with a simultaneous focus on the timing and scale of requisite, managerial governance adaptation, as described by the four cases in Table 1.

Importantly, an MNE's network of subsidiaries is not just the depository of functional knowledge stocks, e.g., in the realm of $R \& D$, production or branding. A bold proposition for IB theorising, aligned with the fourth case in Table 1, is that in large MNEs with widely-dispersed operations, the firm's survival, profitability and growth will sometimes rest with larger-scale governance adaptation, as a delayed response to an accumulation of dispersed (narrow and local) commitment failures. Senior management at the MNE head office will itself typically face significant bounded rationality and bounded reliability challenges when addressing a wide variety of new resource combination efforts that are scattered throughout the company. Expecting swift and efficient responses from senior management, in terms of appropriate governance adaptation to narrow and local failures, is unfortunately unrealistic in many cases, and a far cry from real-world MNE functioning (Forsgren, 2017; Kano $\&$ Verbeke, 2019).

\section{ACKNOWLEDGEMENTS}

The authors are grateful to Mira Wilkins, Geoff Jones, Liena Kano and Rajneesh Narula, who commented on earlier versions of this paper.

\section{NOTES}

${ }^{1}$ This book was published in 1964 and will therefore be subsequently cited as Wilkins \& Hill (1964). The authors, however, used the new 2011 edition that has the same pagination of the text as the 1964 original, but also contains a new introduction by Mira Wilkins and a different pagination of the front matter.

${ }^{2}$ The widely accepted bounded rationality concept was introduced by Herbert Simon. He defined it as behaviour that is 'intendedly rational, but only limitedly so' (Simon, 1961: xxiv). Bounded rationality implies that decision-making is conducted in a sphere of imperfect information and with limited information processing capacity. Commitment failure is thereby a common occurrence, partly because of the manifold uncertainties (technology-related, demand side-related, supply side-elated, regulatory, etc.) associated with strategic decision-making. Here, bounded rationality as a human behavioural assumption - with several variations on the theme - is widely regarded as the main governance challenge to be addressed in organisations, and improving effective information processing capacity is regarded as the main ingredient of governance recipes alleviating this challenge. As regards strong-form self-interest, Williamson (1975: 26-37, 1985: 46-52, 64-67) coined the term opportunism in his oeuvre and defined it as self-interest-seeking with guile.

${ }^{3}$ Many other criticisms have been voiced against Williamsonian TCE, but are less pertinent to the analysis of MNE governance correction undertaken in this paper; see, especially, Ghoshal and Moran (1996) and Kogut and Zander (1993).

${ }^{4}$ Benevolent preference reversal and Identitybased discordance are two broad categories of the sources of bounded reliability. In Verbeke and Greidanus (2009), benevolent preference reversal has two main expressions, namely good faith reprioritisation and scaling back on overcommitment. The former bound on reliability reflects economic actors making commitments in good faith ex ante (with benevolent intent), but the importance of this commitment diminishes over time (preferences are reordered). The latter bound on reliability results from impulsivity and an unrealistic perspective on one's own abilities to make good on an open-ended commitment. The other category, namely identity discordance is defined by Kano and Verbeke (2015) as follows: "This category of bounded reliability refers to 
commitment non-fulfilment due to conflict between 'what one promises' (in good faith) and 'what one represents' or 'values' in terms of one's identity". More specifically, economic actors commit to a course of action in good faith, yet deviate from this agreed-upon course in a way that manifests itself over time. Unlike the case of benevolent preference reversal, neither a shift in timing of delivering on the commitment takes place, nor an adjustment of the commitment itself. Rather, the conflict between promise and identity becomes apparent over time and leads to some disconnect between the promised actions and the realised, identity-driven actions, resulting in a breach of contract or unfulfilled promises. We observed two types of identity-based discordance: (1) internal psychological conflict, whereby individual actors identify with processes, routines and strategies often vestiges of a successful past - that contradict stated or assumed commitments towards leaving behind this past; and (2) inter-group conflict, whereby individuals operating in particular units (either inside the firm or being associated with

\section{REFERENCES}

Bartlett, C. A., \& Ghoshal, S. 2002. Managing across borders: The transnational solution. Boston, Mass: Harvard Business School Press.

Benito, G. R., Petersen, B., \& Welch, L. S. 2009. Towards more realistic conceptualisations of foreign operation modes. Journal of International Business Studies, 40(9): 1455-1470.

Buckley, P. J. 2016. Historical research approaches to the analysis of internationalisation. Management International Review, 56(6): 879-900.

Buckley, P. J. 2018. The global factory: Networked multinational enterprises in the modern global economy. Cheltenham: Edward Elgar.

Buckley, P. J., \& Casson, M. 1976. The future of the multinational enterprise. London: Macmillan.

Buckley, P. J., \& Casson, M. 1981. The optimal timing of a foreign direct investment. The Economic Journal, 91(361): 75-87.

Buckley, P. J., \& Casson, M. C. 1998. Analyzing foreign market entry strategies: Extending the internalization approach. Journal of International Business Studies, 29(3): 539-562.

Buckley, P. J., \& Casson, M. C. 2009. The internalisation theory of the multinational enterprise: A review of the progress of a research agenda after 30 years. Journal of International Business Studies, 40(9): 1563-1580.

Cantwell, J. 2015. The eclectic paradigm: A framework for synthesizing and comparing theories of international business from different disciplines or perspectives. London: Palgrave Macmillan.

Casson, M. 1997. Institutional economics and business history: A way forward? Business History, 39(4): 151-171.

Casson, M. 2018. The multinational enterprise: Theory and history. Cheltenham: Edward Elgar.

Chandler, A. D., \& Salsbury, S. 1971. Pierre S. du Pont and the making of the modern corporation. New York, NY: Harper \& Row. external contracting parties), identify with and pursue appropriate 'local' goals that are misaligned or conflict with those of others, in a way that ultimately diminishes achieving firm-level goals. Based on the above observations, we identified two facets of identity-based discordance: regression and divided engagement."

${ }^{5} \mathrm{~A}$ detailed list of these failures is available from the authors upon request.

${ }^{6}$ In addition to being built on the scholarly insight contained in Willkins \& Hill (1964), this Editorial was directly informed by two "Ford-men", who devoted their professional lives to the Ford Motor Company. Raymond Verbeke (1920-1989) spent the best part of his professional career working for Ford., while Luc Geens (1952-2016) worked his entire career at Ford. Managerial governance in the firm they cherished was the main topic of innumerable conversations with friends and family. They exemplify the many women and men who gave much to the firm, and received much in return.

da Silva Lopes, T., Casson, M., \& Jones, G. 2019. Organizationa innovation in the multinational enterprise: Internalization theory and business history. Journal of International Business Studies, 2019, 1-21.

Doz, Y. L., \& Prahalad, C. K. 1981. Headquarters influence and strategic control in MNCs. Sloan Management Review, 23(1): $15-29$.

Dunning, J. H., \& Lundan, S. M. 2008. Multinational enterprises and the global economy. Cheltenham: Edward Elgar.

Forsgren, M. 2017. Theories of the multinational firm: A multidimensional creature in the global economy (3rd ed.). Cheltenham: Edward Elgar.

Gao, G. Y., \& Pan, Y. 2010. The pace of MNEs' sequential entries: Cumulative entry experience and the dynamic process. Journal of International Business Studies, 41(9): 1572-1580.

Ghoshal, S., \& Moran, P. 1996. Bad for practice: A critique of the transaction cost theory. Academy of Management Review, 21(1): 13-47.

Gill, M. J., Gill, D. J., \& Roulet, T. J. 2018. Constructing trustworthy historical narratives: Criteria, principles and techniques. British Journal of Management, 29(1): 191-205.

Hennart, J. F. 1977. A theory of foreign direct investment. Ph.D. dissertation. College Park, MD: University of Maryland.

Hennart, J. F. 1982. A theory of multinational enterprise. Ann Arbor, MI: University of Michigan.

Hennart, J. F. 2009. Down with MNE-centric theories! Market entry and expansion as the bundling of MNE and local assets. Journal of International Business Studies, 40(9): 1432-1454.

Hutzschenreuter, T., \& Matt, T. 2017. MNE internationalization patterns, the roles of knowledge stocks, and the portfolio of MNE subsidiaries. Journal of International Business Studies, 48(9): 1131-1150.

Jones, G. 2005. Multinationals and global capitalism: From the nineteenth to the twenty first century. Oxford: Oxford University Press. 
Jones, G. 2015. Editor's introduction. Business History Review., 89(3): 403-404.

Kano, L. 2018. Global value chain governance: A relational perspective. Journal of International Business Studies, 49(6): 684-705.

Kano, L., \& Verbeke, A. 2015. The three faces of bounded reliability: Alfred Chandler and the micro-foundations of management theory. California Management Review, 58(1): 97-122.

Kano, L., \& Verbeke, A. 2019. Theories of the multinational firm: A micro-foundational perspective. Global Strategy Journal, 9(1): 117-147.

Kogut, B., \& Zander, U. 1993. Knowledge of the firm and the evolutionary theory of the multinational corporation. Journal of International Business Studies, 24(4): 625-645.

Mees-Buss, J., Welch, C., \& Westney, E. 2019. What happened to the transnational solution? The emergence of the neoglobal corporation. Journal of International Business Studies, 50(9): 761-771.

Narula, R. 2010. Keeping the eclectic paradigm simple. Multinational Business Review, 18(1): 35-50.

Narula, R., Asmussen, C., Chi, T., \& Kundu, S. 2019. Applying and advancing internalization theory: The multinational enterprise in the 21 st century. Journal of International Business Studies.

Narula, R., \& Verbeke, A. 2015. Making internalization theory good for practice: The essence of Alan Rugman's contributions to international business. Journal of World Business, 50(4): 612-622.

Nevins, A. 1964. Preface to the first edition (composed in June 1963). In M. Wilkins \& F. E. Hill (Eds.), American business abroad: Ford on six continents, New edition 2011 (pp. 25-27). New York, NY: Cambridge University Press.

Nordberg, M., \& Verbeke, A. 1999. The strategic management of high technology contracts: The case of CERN: Competence based and transaction cost perspectives. New York, NY: Pergamon.

Penrose, E. T. 1959. The theory of the growth of the firm. New York, NY: Wiley.

Penrose, E. T. 1995. Foreword to the third edition. In E. T. Penrose (Ed.), The theory of the growth of the firm. Oxford: Oxford University Press.

Rugman, A. M. 1981. Inside the multinationals: The economics of internal markets. New York, NY: Columbia University Press.

Rugman, A. M. 2009. The Oxford handbook of international business (2nd ed.). Oxford: Oxford University Press.

Rugman, A. M., \& Verbeke, A. 2002. Edith Penrose's contribution to the resource-based view of strategic management. Strategic Management Journal, 23(8): 769-780.

Rugman, A. M., Verbeke, A., \& Yuan, W. 2011. Re-conceptualizing Bartlett and Ghoshal's classification of national subsidiary roles in the multinational enterprise. Journal of Management Studies, 48(2): 253-277.

Simon, H. A. 1961. Administrative behavior (2nd ed.). New York, NY: Macmillan.

Stopford, J. M., \& Wells, L. T., Jr. 1972. Managing the multinational enterprise: Organization of the firm and ownership of the subsidiary. New York, NY: Basic Books.

Strange, R., \& Humphrey, J. 2019. What lies between market and hierarchy? Insights from internalization theory and global value chain theory. Journal of International Business Studies. https://doi.org/10.1057/s41267-018-0186-0

Teece, D. J. 2014. A dynamic capabilities-based entrepreneurial theory of the multinational enterprise. Journal of International Business Studies, 45(1): 8-37.

Verbeke, A. 2013. International business strategy (2nd ed.). Cambridge: Cambridge University Press.

Verbeke, A., \& Greidanus, N. 2009. The end of the opportunism vs. trust debate: Bounded reliability as a new envelope concept in research on MNE governance. Journal of International Business Studies, 40(9): 1471-1495.

Verbeke, A., \& Kenworthy, T. P. 2008. Multidivisional vs. metanational governance of the multinational enterprise. Journal of International Business Studies, 39(6): 940-956.

Wilkins, M. 2009. The history of multinational enterprise. In A. M. Rugman (Ed.), The Oxford handbook of international business (2nd ed., pp. 3-35). Oxford: Oxford University Press.

Wilkins, M., \& Hill, F. E. 1964. American business abroad: Ford on six continents. New edition, 2011, Cambridge, UK: Cambridge University Press.

Williamson, O. E. 1975. Markets and hierarchies: Analysis and antitrust implications: $A$ study in the economics of internal organization. New York, NY: The Free Press.

Williamson, O. E. 1985. The economic institutions of capitalism. New York, NY: The Free Press.

Williamson, O. E. 1996. The mechanisms of governance. New York, NY: Oxford University Press.

Williamson, O. E. 2013. The transaction cost economics project: The theory and practice of the governance of contractual relations. Cheltenham: Edward Elgar.

Zeng, R., Grøgaard, B., \& Steel, P. 2018. Complements or substitutes? A meta-analysis of the role of integration mechanisms for knowledge transfer in the MNE network. Journal of World Business, 53(4): 415-432.

Publisher's Note Springer Nature remains neutral with regard to jurisdictional claims in published maps and institutional affiliations. 